\title{
ARTICLE
}

\section{Why Protect Ancient Woodland in the UK? Rethinking the Ecosystem Approach}

\author{
Jona Razzaque* $($ ) and Claire Lester**
}

First published online 17 November 2020

\begin{abstract}
Sites of ancient woodland in the United Kingdom (UK) are diminishing rapidly and the multifunctional forest management system with its fragmented approach fails effectively to protect such woodland. In the face of reports on the destruction of ancient woodland, the HS2 HighSpeed train project in the UK signifies the extent of trade-offs among the key stakeholders. Such large infrastructure projects typically come with high environmental and social costs, including deforestation, habitat fragmentation, biodiversity loss, and social disruption. This article examines the protection of ancient woodland in the UK and assesses the challenges in applying the ecosystem approach, an internationally recognized sustainability strategy, in the context of such protection. A better understanding of the ecosystem approach to manage ancient woodland is critical for promoting sustainable forestry practices in the UK and informs the discussion in this article of the importance of conserving ancient woodland globally. Lessons learned from UK woodland policies and certification schemes include the need to have in place strong regulatory frameworks, introduce clear indicators, and recognize pluralistic value systems alongside economic considerations. The article concludes that the protection of ancient woodland in the UK requires distinct and strong laws that reflect multiple values of this resource, acknowledge the trade-offs among stakeholders, and adopt an inclusive approach to reduce power asymmetries.
\end{abstract}

Keywords: Ancient woodland, Ecosystem approach, Certification, United Kingdom, Forestry

\section{INTRODUCTION}

The forests of the United Kingdom (UK) differ from those in other countries, including those with similar ecological and economic climates. The industrial revolution concentrated on quick-growing woodland with good logging potential, ${ }^{1}$ and the immediate

* University of the West of England (UWE), Bristol Law School, Bristol (United Kingdom (UK)). Email: Jona.Razzaque@uwe.ac.uk.

** University of the West of England (UWE), Bristol Law School, Bristol (UK).

Email: Lester.claire@outlook.com.

We are grateful to the reviewers for comments that helped to develop the arguments in this article.

1 S. Raum \& C. Potter, 'Forestry Paradigms and Policy Change: The Evolution of Forestry Policy in Britain in Relation to the Ecosystem Approach' (2015) 49(462) Land Use Policy, pp. 462-70, at 464. 
need for wood during the two World Wars meant little forward thinking occurred and woodland became depleted. Forest diminished quickly, causing damage that could last for centuries ${ }^{2}$ and making natural regrowth difficult. ${ }^{3}$ Gradually, a multifunctional management system evolved which considered the wider effects and benefits of forests. ${ }^{4}$ The UK experimented with different management styles to protect existing and create new woodland, aimed at swift implementation to stop further damage and create a long-term perspective. ${ }^{5}$ Even though the current focus is on maintenance and replanting, woodland covers a mere $13 \%{ }^{6}$ of UK's total landmass, which is well below average for Europe. 7

Globally the scale of forest degradation has led to the proliferation of regulations, challenged the adequacy of traditional state-centred laws and pushed for the active involvement of a wide range of non-state actors as well as transnational networks. ${ }^{8}$ Large infrastructure projects (such as roads, highways, and rail networks) in the global north and the south also come with high environmental and social costs, including biodiversity loss, deforestation, and social disruption. ${ }^{9}$ The inherent anthropocentricity of such large infrastructure projects is apparent in the assessment of the relative costs and benefits that accompany them, and in their prioritization of benefits for humanity. Any forest regulation now faces the difficult tasks of balancing the conservation and exploitation of forests, accommodating global forest management approaches, recognizing the multiple values and services offered by forests, and being more inclusive of the social, political, and cultural dimensions of forest use.

Responding to the increased awareness of ecological and environmental impacts, the UK applies the ecosystem approach (EcAp) to woodland management. The aims of this dynamic approach are not only to focus on woodland as a separate concern but also, as part of a greater society, to integrate multiple values and offer benefits for people and the economic health of the country. ${ }^{10}$ Thus, the question is whether the EcAp is effectively applied in the protection of ancient woodland (AW).

2 J.L. Dupouey et al., 'Irreversible Impact of Past Land Use on Forest Soils and Biodiversity' (2002) 83(11) Ecology, pp. 2978-84.

3 E. Goldberg et al., 'The Ancient Woodland Concept as a Practical Conservation Tool in Great Britain' (2007) 15(2) Journal for Nature Conservation, pp. 109-19.

4 Raum \& Potter, n. 1 above, p. 468.

5 A.D. Brown, 'Pollen Analysis and Planted Ancient Woodland Restoration Strategies: A Case Study from the Wentwood, Southeast Wales, UK' (2010) 19(2) Vegetation History and Archaeobotany, pp. 79-90.

6 The area of woodland in the UK in 2019 is estimated to be 3.19 million hectares: Forest Research, 'Forestry Statistics 2019', 26 Sept. 2019, available at: https://www.forestresearch.gov.uk/tools-andresources/statistics/forestry-statistics/forestry-statistics-2019.

7 L.A. Sutherland \& S. Huttunen, 'Linking Practices of Multifunctional Forestry to Policy Objectives: Case Studies in Finland and the UK' (2018) 86(35) Forest Policy and Economics, pp. 35-44.

8 A. Agrawal, A. Chhatre \& R. Hardin, 'Changing Governance of the World's Forests' (2008) 320(5882) Science, pp. 1460-62.

9 S. Sloan et al., 'Infrastructure Development and Contested Forest Governance Threaten the Leuser Ecosystem, Indonesia' (2018) 77 Land Use Policy, pp. 298-309; M. Alamgir et al., 'Economic, Socio-Political and Environmental Risks of Road Development in the Tropics' (2017) 27(20) Current Biology, pp. R1130-R1140.

10 UK Department for Environment, Food \& Rural Affairs (DEFRA), 'Ecosystem Services,' 12 Nov. 2014, available at: https://www.gov.uk/guidance/ecosystems-services. 
Much research has been conducted into forests across Europe but very few publications examine the impacts of the EcAp on UK forestry. ${ }^{11}$ Further exploration is also needed into the intrinsic value of AW as an important ecosystem and its future protection. Noting the focus of this article, a literature search was conducted for the 'ecosystem approach', which selected papers based on their relevance to 'ancient woodlands', the challenges to implement the EcAp in UK forestry policies, and the role of international certification schemes in the protection of AW. References to the 'ecosystem approach' can be found in the academic literature since the late 1950s. Other approaches developed over time - such as the 'ecosystem services approach', 'ecosystem-based management', 'ecosystem management', and 'sustainable forest management' - can also be linked to the EcAp. ${ }^{12}$ This article examines the special characteristics of AW, assesses the challenges in applying the EcAp to its protection and, in this context, examines the laws, policies and certification schemes in the UK. It argues that AW protection in the UK will require distinct and strong laws that integrate the plurality of values of AW, acknowledge the trade-offs among stakeholders, and adopt an inclusive approach to reduce existing power asymmetries.

\section{ANCIENT WOODLAND IN THE UK: CHALLENGES, INTERPLAY, AND TRADE-OFFS}

AW is irreplaceable; examples of its legal protection in Europe and North America underscore its high conservation value and global importance. ${ }^{13}$ Even though AW occupies just $2.4 \%$ of the UK landmass, it is unique. ${ }^{14}$ It offers a plethora of habitats that cannot be found elsewhere, making it vitally important for wildlife and biodiversity. ${ }^{15} \mathrm{AW}$ is defined by the Food and Agriculture Organization (FAO) of the United Nations (UN) as a 'woodland that has been in continuous existence since 1600 (1750 in Scotland)'. ${ }^{16}$ This is a simple definition that does not explain the unique features of AW. The longer period of development of woodland offers a chance to thrive

11 S. Raum, 'The Ecosystem Approach, Ecosystem Services and Established Forestry Policy Approaches in the United Kingdom' (2017) 64 Land Use Policy, pp. 282-91.

12 K.A. Waylen et al., 'The Need to Disentangle Key Concepts from Ecosystem-Approach Jargon' (2014) 28(5) Conservation Biology, pp. 1215-24; Convention on Biological Diversity (CBD) Secretariat, 'Ecosystem Approach' (27 Feb. 2004), UN Doc. UNEP/CBD/COP/DEC/VII/11, available at: https://www.cbd.int/doc/decisions/cop-07/cop-07-dec-11-en.pdf.

13 While the term 'ancient forest' or 'ancient woodland' is commonly used in the UK, in North America and Europe, the term 'old-growth forest' is used: EUROPARC-España, 'Old-Growth Forests: Characteristics and Conservation Value', Dec. 2017, available at: http:/www.europarc.org/wp-content/uploads/2018/ 03/OLD-GROWTH-FORESTS-Manual_english.pdf.

14 AW covers $18.5 \%$ of the UK's woodland area. The majority of AW is located in England; its extent and distribution is based on the Ancient Woodland Inventory: Woodland Trust, 'The Current State of Ancient Woodland Restoration', Jan. 2018, available at: https://www.woodlandtrust.org.uk/media/1704/current-state-of-ancient-woodland-restoration.pdf.

15 UK Houses of Parliament, Parliamentary Office of Science and Technology, 'Ancient Woodland', Post Note No. 465, June 2014, available at: http://researchbriefings.files.parliament.uk/documents/POSTPN-465/POST-PN-465.pdf.

16 FAO, 'Global Forest Assessment 2015 - Country Report: United Kingdom of Great Britain and Northern Ireland', 2014, available at: http://www.fao.org/3/a-az365e.pdf. 
for species that mature, colonize, and pollinate slowly. ${ }^{17}$ The soil resulting from this woodland development also has its own rich nutrients which makes it the perfect environment for rare types of fungus and insect. ${ }^{18}$ From a global perspective, these are just a few of the ecological benefits of AW alongside flood mitigation, fuel production, and carbon sequestration. ${ }^{19} \mathrm{AW}$ also has cultural importance, ${ }^{20}$ it provides both physical places of importance, such as sacred areas, ${ }^{21}$ and immeasurable benefits, such as its key role in the stories and mysteries that surround the Dartmoor woods in the UK. ${ }^{22}$

AW in the UK is categorized into two groups: Ancient Semi-Natural Woodland (ASNW) sites, which house native non-planted trees, and Plantations on Ancient Woodland Sites (PAWS), which are often planted with some non-native species. ${ }^{23}$ The ASNW sites are the most valued as they are regarded as the closest to a completely natural woodland, although still requiring management to maintain and protect the ecosystem. The volume of ASNW sites is declining or being converted into PAWS, ${ }^{24}$ which tends to emphasize economic values over environmental benefits. ${ }^{25}$ However, PAWS still retain some of the species and characteristics of an ASNW site. Both categories need protection to keep woodland management in the UK sustainable.

There are several threats to AW in the UK. Firstly, changes in the AW environment can have severe effects and, as the ecosystem needs a long period in which to develop its unique biodiversity, these effects can be irreversible. For instance, long-term climate change, leading to harsher and wetter winters, can kill saplings; long, dry summers can slow down tree growth. ${ }^{26}$

Secondly, fragmentation is a huge threat to AW as it obstructs pollination, especially for native trees with shorter pollination distances, and leaves woods vulnerable to edge effects where damage is caused through contamination from adjacent non-ancient woods or farmland. ${ }^{27}$ For example, damage from pesticides used on nearby agricultural land ${ }^{28}$ can affect both soil nutrients and trees. ${ }^{29}$ AW cannot spread because of

17 S.N. Pryor, T.A. Curtis \& G.F. Peterken, 'Restoring Plantations on Ancient Woodland Sites', 2002, available at: https://pdfs.semanticscholar.org/2de9/526c1882e7912f9ffc7521d56557b56ce9bf.pdf.

18 Dupouey et al., n. 2 above, p. 2983.

19 UK Houses of Parliament, n. 15 above; EUROPARC-España, n. 13 above; A. Mosseler, I. Thompson \& B. Pendrel, 'Overview of Old-Growth Forests in Canada from a Science Perspective' (2003) 11(S1) Environmental Reviews, pp. 1-7.

20 FAO, n. 16 above.

21 UK Houses of Parliament, n. 15 above.

22 P. Smith, 'Copying Ancient Woodlands: A Positive Perspective' (2018) 27(5) Biodiversity and Conservation, pp. 1041-53.

23 Brown, n. 5 above, p. 81-82.

24 Pryor, Curtis \& Peterken, n. 17 above.

25 O. Rackham, 'Ancient Woodlands: Modern Threats' (2008) 180(3) New Phytologist, pp. 571-86.

26 Ibid.

27 T. Riutta et al., 'Living on the Edge: Quantifying the Structure of a Fragmented Forest Landscape in England' (2014) 29(6) Landscape Ecology, pp. 949-61.

28 M. Schmidt et al., 'Determining Ancient Woodland Indicator Plants for Practical Use: A New Approach Developed in Northwest Germany' (2014) 330 Forest Ecology and Management, pp. 228-39.

29 Dupouey et al., n. 2 above. 
the vast tracts of land between the woods. Intervention using careful planting and pollination management is therefore needed. ${ }^{30}$

Thirdly, non-native trees, plants, and animals have been introduced into the UK with negative impacts. Sometimes such initiatives, intended to contribute to the preservation of species such as deer, ${ }^{31}$ have proved counterproductive. Deer in Scotland have caused damage, through excessive grazing, ${ }^{32}$ to ground-level plants that support the AW ecosystem. ${ }^{33}$ These initiatives can also be for ease and profit - for example, fast-growing American conifers have more logging potential, ${ }^{34}$ but they fight for canopy space and overtake slower-growing native species of broadleaf. ${ }^{35}$ All over Ireland, for instance, the increased volume of imported tree species caused the inflation of the grey squirrel population, which changed the nature of the ecosystem and resulted in the depletion of native red squirrels, which are now endangered. ${ }^{36}$

Fourthly, close planting and invasive alien species brought into the UK (such as plants, mammals, and insects) ${ }^{37}$ have increased the amount of disease which, in turn, threatens the health of all woodland, including AW. As part of the UK Forest Standards, landowners and communities must take responsibility for managing diseases through prioritizing, identifying, reporting, and removing diseased trees. ${ }^{38}$ Indeed, the reduced volume of woodland means that they are more easily monitored and measured. ${ }^{39}$ However, it is a continuous concern that requires considerable time and effort.

Fifthly, the private ownership of woodland causes substantial complications. Financial limitations and the need for specialist knowledge to effectively manage AW make it impossible for a single stakeholder to successfully protect the resource. At the same time, the presence of multiple stakeholders can cause further complications, as their divergent views can lead to conflicts of interest, trade-offs, and an imbalance of power. Landowners and managers hold decision-making powers but also operate in a complicated hierarchy of power, as the tenure of forests means that land may be

30 Rackham, n. 25 above.

31 Ibid.

32 Forestry Commission England, 'Managing Ancient and Native Woodland in England', 1 Jan. 2010, available at: https://www.gov.uk/government/publications/managing-ancient-and-native-woodland-inengland.

33 UK Houses of Parliament, n. 15 above.

34 Pryor, Curtis \& Peterken, n. 17 above.

35 K.J. Kirby, 'Changes in the Ground Flora under Plantations on Ancient Woodland Sites' (1988) 61(4) International Journal of Forest Research, pp. 317-38.

36 C. Bullock, J. Hawe \& D. Little, 'Realising the Ecosystem-Service Value of Native Woodland in Ireland' (2014) 44(Suppl 1) New Zealand Journal of Forestry Science, pp. 1-10.

37 Welsh Assembly Government, 'Policy Position in Support of Woodlands for Wales, WAG's Strategy for Woodlands and Trees: Biodiversity', Apr. 2011, available at: https:/gov.wales/sites/default/files/publications/2018-03/woodlands-for-wales-biodiversity.pdf.

38 Forestry Commission England et al., The UK Forestry Standard: The Government's Approach to Sustainable Forestry (Forestry Commission, 2017), available at: https://assets.publishing.service.gov. uk/government/uploads/system/uploads/attachment_data/file/687147/The_UK_Forestry_Standard.pdf.

39 DEFRA, 'Government Forestry and Woodland Policy Statement: Incorporating the Government's Response to the Independent Panel on Forestry's Final Report', Jan. 2013, available at: https://assets.pub lishing.service.gov.uk/government/uploads/system/uploads/attachment_data/file/221023/pb13871-forestrypolicy-statement.pdf. 
managed by either owners, leaseholders, or managers. ${ }^{40}$ Each group has its own aims, with some being of a short-term nature, others more long-term. ${ }^{41}$ Stakeholders may show interest, for instance, in recreating AW among other habitats ${ }^{42}$ and using agroforestry. ${ }^{43}$ However, there needs to be a level of compromise between woodland conservation and profitability. ${ }^{44}$

Some non-governmental organizations (NGOs) act as managers or owners of AW. For example, the National Trust for Places of Historic Interest or Natural Beauty (known as the National Trust) is Europe's largest conservation charity with the task of looking after 'nature, beauty and history for the nation to enjoy', including AW. ${ }^{45}$ The largest and best-known NGO stakeholder in the UK is the Woodland Trust, which 'aims to restore planted ancient woodland, buffer existing sites and prevent further destruction'. 46 The Woodland Trust has a large stakeholder focus involving communities in volunteering (on which their work relies ${ }^{47}$ ) and encouraging community ownership. ${ }^{48}$ These efforts attempt to bridge gaps between stakeholders and make coherent plans for woodland. Other environmental, charitable, and social groups are becoming influential stakeholders as they gain ownership of woodland. ${ }^{49}$ There are many groups with various opinions and skills. Maintaining cooperation is therefore especially difficult, as many woodlands are privately owned, which makes policy and legislation hard to implement as it hinges on the willingness of owners to cooperate. In addition to the governance issues involved in privately owned woodland, responsibility for the management of publicly owned forests rests with the Forestry Commission, a non-ministerial government department, which regulates both public and private forestry in England. ${ }^{50}$ It should be noted that forest management in the UK is devolved to the governments of Scotland, Wales, and Northern Ireland, which creates additional complexity for tracking AW protection in the UK. In 2019, the area of woodland in the

40 S. Atkinson \& M. Townsend, 'The State of the UK's Forests, Woods and Trees', Woodland Trust, 2011, available at: https://www.woodlandtrust.org.uk/mediafile/100229275/stake-of-uk-forest-report.pdf?cb= $58 \mathrm{~d} 97 \mathrm{f} 320 \mathrm{c}$.

41 Ibid.

42 A. Davies, 'Long-Term Approaches to Native Woodland Restoration: Palaeoecological and Stakeholder Perspectives on Atlantic Forests of Northern Europe' (2011) 261(3) Forest Ecology and Management, pp. 751-63.

43 S. Garcia de Jalon et al., 'How Is Agroforestry Perceived in Europe? An Assessment of Positive and Negative Aspects by Stakeholders' (2018) 92(4) Agroforestry Systems, pp. 829-48.

44 Ibid.

45 National Trust, 'Ancient Woodland', available at: https://www.nationaltrust.org.uk/features/ancientwoodland.

46 Woodland Trust, 'Ancient Woodland', available at: https://www.woodlandtrust.org.uk/trees-woodsand-wildlife/habitats/ancient-woodland.

47 Woodland Trust, 'Management of our Woods', available at: https://www.woodlandtrust.org.uk/mediafile/100083897/Management-of-our-Woods.pdf.

48 Woodland Trust, 'Community Ownership for Woodland Management and Creation', July 2011, available at: https://www.woodlandtrust.org.uk/publications/2011/07/community-ownership-for-woodlandmanagement-and-creation.

49 A. Ludvig et al., 'Social Innovation in the Welsh Woodlands: Community Based Forestry as Collective Third Sector Engagement' (2018) 95 Forest Policy and Economics, pp. 18-25.

50 Forestry Commission, 'About Us', available at: https://www.gov.uk/government/organisations/forestrycommission/about. 
UK was estimated to be 3.19 million hectares. Of that, 0.86 million hectares are owned or managed by the Forestry Commission (in England) along with Forestry and Land Scotland, Natural Resources Wales or the Forest Service (in Northern Ireland). ${ }^{51}$

The challenges to the protection of AW have detrimental effects on forests and, along with poor management or uninformed decisions, contribute to the decline of AW in the UK. These challenges are comparable with those facing AW protection in North America and Europe, ranging from information constraints and inadequate financial incentives to a lack of integrated and inclusive management practices to protect AW. ${ }^{52}$ This decline of AW in the UK can be combated only through acknowledging the (economic, societal, physical) context and viewing woodland for its multiple values, including intrinsic, instrumental, economic, and relational values. ${ }^{53}$ It is argued that the EcAp can assist in recognizing the potential benefits and risks of integrating these factors into decision making. The EcAp can be a conduit in taking into account the contribution of all stakeholders involved to better manage the land and maintain its functions and biodiversity. The potential for the EcAp to contribute to AW protection is explored further in the next section.

\section{WHY APPLY THE ECOSYSTEM APPROACH TO PROTECT ANCIENT WOODLAND?}

Ecosystems are vital for the environment in order to sustain life and resources and to support human society and its development. This role of the ecosystem is recognized in the 2005 Millennium Ecosystem Assessment ${ }^{54}$ as well as the 2019 Global Assessment on Biodiversity and Ecosystem Assessment, ${ }^{55}$ which provide scientific backing for conservation action. Reference to the EcAp is found, for example, in the 2002 World Summit on Sustainable Development, ${ }^{56}$ the UN Convention on the Law

51 Forest Research, 'Forestry Statistics 2019', 26 Sept. 2019, available at: https://www.forestresearch.gov. uk/tools-and-resources/statistics/forestry-statistics/forestry-statistics-2019.

52 S. Burrascano et al., 'Commonality and Variability in the Structural Attributes of Moist Temperate Old-Growth Forests: A Global Review' (2013) 291 Forest Ecology and Management, pp. 458-79; R. Grindean, I. Tanţău \& A. Feurdean, 'Linking Vegetation Dynamics and Stability in the Old-Growth Forests of Central Eastern Europe: Implications for Forest Conservation and Management' (2019) 229 Biological Conservation, pp. 160-9; R. Bullock, K. Jastremski \& M.G. Reed, 'Canada's Model Forests 20 years On: Towards Forest and Community Sustainability?' (2017) 41(3) Natural Resources Forum: A United Nations Sustainable Development Journal, pp. 15666; A. Barton \& W.S. Keeton (eds), Eastern Old-Growth Forests: Ecology and Recovery in a Changing World (Island Press, 2018).

53 Intergovernmental Science-Policy Platform on Biodiversity and Ecosystem Services (IPBES), 'Preliminary Guide regarding Diverse Conceptualization of Multiple Values of Nature and Its Benefits, including Biodiversity and Ecosystem Functions and Services', IPBES/4/INF/13, Dec. 2015, available at: https://ipbes.net/sites/default/files/downloads/IPBES-4-INF-13_EN.pdf.

54 Millennium Ecosystem Assessment, 'Global Assessment Reports' (2005), available at: http://www.millenniumassessment.org/en/index.aspx.

55 S. Díaz et al., Summary for Policymakers of the Global Assessment Report on Biodiversity and Ecosystem Services of the Intergovernmental Science-Policy Platform on Biodiversity and Ecosystem Services (IPBES, 2019), available at: https://ipbes.net/sites/default/files/2020-02/ipbes_global_assessment_report_summary_for_policymakers_en.pdf.

56 World Summit on Sustainable Development, 'Plan of Implementation', Part IV: 'Protecting and Managing the Natural Resource Base of Economic and Social Development', 4 Sept. 2002, para. 42, available at: https://sustainabledevelopment.un.org/milesstones/wssd. 
of the Sea (UNCLOS), ${ }^{57}$ multiple UN General Assembly Resolutions, ${ }^{58}$ and the UN Convention on the Non-Navigational Uses of International Watercourses. ${ }^{59}$ The EcAp is also applied at the regional level, for instance, in the UN Economic Commission for Europe (UNECE) Convention on the Protection and Use of Transboundary Watercourses and International Lakes (Helsinki Convention). ${ }^{60}$ The following discussion will focus on the devolved nature of the EcAp in protecting AW, with the High-Speed2 rail project in the UK as an example.

\subsection{The Ecosystem Approach}

The Convention on Biological Diversity $(\mathrm{CBD})^{61}$ defines the EcAp as 'a strategy for the integrated management of land, water and living resources that promotes conservation and sustainable use in an equitable way'. ${ }^{62}$ The CBD supplies the most comprehensive explanation of the EcAp, with principles and operational guidelines providing a methodology which can be implemented, measured and valued in monetary terms. ${ }^{63}$ Once this definition is unpacked, 12 principles emerge as a benchmark. According to these principles, an EcAp should: (1) manage land, water and living resources; (2) be decentralized; (3) consider the effects on adjacent land or ecosystems; (4) view the ecosystem in an economic context; (5) maintain ecosystem services; (6) manage ecosystems within their limits; (7) be undertaken at the appropriate spatial and temporal scale; (8) take a long-term perspective; (9) recognize that change is inevitable; (10) balance and integrate conservation and use of biodiversity; (11) consider all forms of relevant information; and (12) consider relevant sectors of society and science. ${ }^{64}$ These principles help to shape ideas on how to implement the EcAp to protect the forest ecosystems of the UK.

The EcAp principles also help in drawing attention to the integration of various legal and management strategies; the balancing of conservation and sustainable use of

57 Montego Bay (Jamaica), 10 Dec. 1982, in force 16 Nov. 1994, available at: http://www.un.org/depts/los/ convention_agreements/texts/unclos/closindx.htm; Division for Ocean Affairs and the Law of the Sea, 'Ecosystem Approaches', available at: https://www.un.org/Depts/los/ecosystem_approaches/ecosystem_ approaches.htm.

58 E.g., Resolution adopted by the UN General Assembly (UNGA), 'Oceans and the Law of the Sea' (7 Dec. 2010), UN Doc. A/RES/65/37; UNGA Resolution 60/31, 'Sustainable Fisheries' (29 Nov. 2005), UN Doc. A/RES/60/31.

59 New York, NY (US), 21 May 1997, in force 17 Aug. 2014, UN Doc. A/RES/51/229, Art. 20, available at: http://untreaty.un.org/ilc/texts/instruments/english/conventions/8_3_1997.pdf.

60 Helsinki (Finland), 17 Mar. 1992, in force 6 Oct. 1996, UN Doc. E/ECE 1267 (1992), Art. 2(2)(b), available at: http://www.unece.org/env/water. See also O. McIntyre, 'The Protection of Freshwater Ecosystems Revisited: Towards a Common Understanding of the "Ecosystems Approach" to the Protection of Transboundary Water Resources' (2014) 23(1) Review of European Comparative and International Environmental Law, pp. 88-95.

61 Rio de Janeiro (Brazil), 5 June 1992, in force 29 Dec. 1993, available at: http://www.cbd.int/convention/ text.

62 Ibid., Art. 2.

63 CBD Secretariat, 'Operational Guidance for Application of the Ecosystem Approach', 18 Mar. 2010, available at: https://www.cbd.int/ecosystem/operational.shtml; see also V. de Lucia, 'Competing Narratives and Complex Genealogies: The Ecosystem Approach in International Environmental Law' (2015) 27(1) Journal of Environmental Law, pp. 91-117.

64 CBD Secretariat, 'Ecosystem Approach: Principles', 7 Feb. 2007, available at: https://www.cbd.int/ecosystem/principles.shtml. 
biodiversity; cooperation among different stakeholders; and the negotiation of tradeoffs between human and environmental needs. ${ }^{65}$ The EcAp can be a useful tool and be adapted to any situation, although its vague definition and the lack of measurable targets can make it a complicated approach to implement in practice. Furthermore, the holistic, long-term approach which the EcAp represents may necessitate trade-offs, some of which are unpredictable. This uncertainty adds an element of risk that could deter some actors - such as forest managers, owners and government agencies from integrating EcAp in woodland management practices. Nonetheless, with any management approach, trade-offs occur as a result of the complicated web of interests surrounding land use and forest management. ${ }^{66}$

The challenges associated with the implementation of the EcAp include poor understanding of ecological processes, the complexity of socio-ecological systems, and the lack of effective involvement of stakeholders. ${ }^{67}$ On the one hand, the fragmentation of woodland which jeopardizes the maintenance of ecosystem integrity and, on the other hand, the wide discretion of the decision makers in weighing in diverse values exacerbate the difficulties inherent in balancing conservation and sustainable biodiversity use. ${ }^{68}$ The unrelenting effort to balance between conservation and sustainability, between economic gain and non-economic values, and between national and local interests highlights the continuous struggle to prioritize the integrity of ecosystems. ${ }^{69}$

Challenges aside, there is no doubt that the EcAp highlights intangible woodland benefits which can make AW management more attractive to landowners and managers by revealing unseen benefits and long-term assets. ${ }^{70}$ It can promote woodland management plans that integrate appropriate participatory processes, adaptive management, and partnerships. ${ }^{71}$ The EcAp principles also underscore that the EcAp aims to protect ecosystems that are hard to quantify and value within an economic context. Nevertheless, the integration of all EcAp principles into one programme or project remains difficult and may not be 'feasible in every site or situation'. ${ }^{72}$ The parallel application of 'distinctly different but interrelated' forest conservation approaches (such as the ecosystem management approach and ecosystem services approach $)^{73}$ and the

65 E. Morgera, 'The Ecosystem Approach and the Precautionary Principle', in E. Morgera \& J. Razzaque (eds), Biodiversity and Nature Protection Law (Edward Elgar, 2015), pp. 70-80.

66 L. Sing et al., 'A Review of the Effects of Forest Management Intensity on Ecosystem Services for Northern European Temperate Forests with a Focus on the UK' (2018) 91(2) Forestry: An International Journal of Forest Research, pp. 151-64.

67 Waylen et al., n. 12 above.

68 F.M. Platjouw, Environmental Law and the Ecosystem Approach: Maintaining Ecological Integrity through Consistency in Law (Routledge, 2016), pp. 1-18.

69 Morgera, n. 65 above.

70 Bullock, Hawe \& Little, n. 36 above.

71 Smith, n. 22 above

72 Waylen et al., n. 12 above.

73 Raum, n. 11 above. For the difference between the ecosystem approach, ecosystem services approach and ecosystem management approach, see Waylen et al., n. 12 above, p. 1218. Ecosystem services are benefits that people obtain from ecosystems and can be divided into supporting, regulating, provisioning, and cultural services; the ecosystem management approach maintains or restores the composition, structure, 
'arbitrary order' of the 12 EcAp principles ${ }^{74}$ creates another level of confusion and uncertainty in implementing the EcAp in AW protection in the UK.

The UK uses specific indicator species of trees, plants, and animals which have been identified to enable data gathering on AW. ${ }^{75}$ These indicators show the diversity of the ecosystem and signify its resilience and the predicted consequence of different management practices. The indicators, alongside other data such as information on species loss, can be used within the EcAp to take into account multiple values of AW and its benefits, and assess trade-offs. ${ }^{76}$ This process, when viewed in a holistic manner, can help governments in balancing the various interests (national and local, economic and non-economic), which enables long-term planning. Furthermore, the EcAp can engage with multiple values through systems such as the Ecosystem Service Valuation Assessment or Ecosystem Service Valuation, ${ }^{77}$ thus giving qualitative valuation factors more weight in assessment and serving as a useful decision-making tool for all stakeholders. While this kind of approach helps to highlight the importance of AW features that are not usually considered when calculating a woodland's multiple values, there is a fear that it can also lead to vague overarching management suggestions. ${ }^{78}$

\subsection{High-Speed2 Railway Project in the UK}

One example of the challenges in implementing the EcAp in the context of AW conservation is the High-Speed2 (HS2) railway project in the UK. It is one of many examples from around the world of large infrastructure projects that threaten to destroy AW. ${ }^{79}$ The UK HS2 project is due to be completed in two phases. The first phase of the project (between London and the West Midlands) received parliamentary approval in $2017 .{ }^{80}$ Phase 2 is split into two sub-phases: Phase 2 a runs from the West Midlands to Crewe; Phase $2 \mathrm{~b}$ goes from Crewe to Manchester, and from the West Midlands to Leeds. The content of the High-Speed Rail (West Midlands - Crewe) Bill ${ }^{81}$ deals with Phase $2 \mathrm{a}$ of

function, and delivery of services of natural and modified ecosystems for the goal of achieving sustainability: see IPBES, 'Glossary', available at: https://ipbes.net/glossary.

74 G. Shepherd, 'Overview', in G. Shepherd (ed.), The Ecosystem Approach: Learning from Experience (International Union for the Conservation of Nature (IUCN), 2008), pp. 1-22, at 4, available at: https://www.cbd.int/doc/external/iucn/iucn-ecosystem-approach-en.pdf.

75 Schmidt et al., n. 28 above.

76 M. Makkonen et al., 'Policy Coherence in Climate Change Mitigation: An Ecosystem Service Approach to Forests as Carbon Sinks and Bioenergy Sources' (2015) 50(C) Forest Policy and Economics, pp. 153-62.

77 UK Houses of Parliament, Parliamentary Office of Science and Technology, 'The Ecosystem Approach', Post Note No. 377, May 2011, available at: https://www.parliament.uk/documents/post/postpn_377ecosystem-approach.pdf.

78 C. Quine, S. Bailey \& K. Watts, 'Sustainable Forest Management in a Time of Ecosystem Services Frameworks: Common Ground and Consequences' (2013) 50(4) Journal of Applied Ecology, pp. 863-7.

79 Alamgir et al., n. 9 above; M. Alamgir et al., 'High-Risk Infrastructure Projects Pose Imminent Threats to Forests in Indonesian Borneo' (2019) 9(1) Scientific Reports, pp. 1-10; C.J. Kettle \& L.P. Koh (eds), Global Forest Fragmentation (CABI, 2014).

80 UK Department of Transport, 'HS2', available at: https://www.gov.uk/government/organisations/highspeed-two-limited.

81 UK Parliament, 'High Speed Rail (West Midlands - Crewe) Bill', Department of Transport Hybrid Bill, 2017-19, available at: https://services.parliament.uk/bills/2017-19/highspeedrailwestmidlandscrewe.html. 
the HS2 project and has been heavily contested since its creation in $2017 .{ }^{82}$ In addition to the potential impact of the Bill on existing rights of way, ${ }^{83}$ the train line would cause loss of AW and damage to woodland through edge effects and pollution. However, this infrastructure project is seen as vital by the UK Department of Transport. The contentious project has raised concerns among environmental experts since the 1990s over the potential damage to AW and danger from trees falling on the line, ${ }^{84}$ and environmental concerns quickly developed as plans progressed. According to a UK Environmental Audit Committee Report, 19 areas of AW covering 32 hectares will be affected by the project. ${ }^{85}$ The HS2 Action Alliance (comprising stakeholders and groups opposing the HS2 project) challenged the UK government in court ${ }^{86}$ on ten counts, including complaints that the project does not comply with the European Union (EU) Habitats Directive, ${ }^{87}$ the Strategic Environmental Assessment Directive, ${ }^{88}$ and the Environmental Impact Assessment Directive. ${ }^{89}$ This case went to the Supreme Court on appeal, where it was dismissed in $2013^{90}$ on the ground that some of the laws were not relevant to the HS2 project and that the government had conducted an adequate assessment of environmental risks. ${ }^{91}$ Despite this ruling, two major criticisms of the project remain: a more inclusive approach is needed to bring together stakeholders; and the government should take into account the loss of benefits and multiple values provided by AW.

The HS2 project's environmental statement, produced by High Speed Two (HS2) Ltd, ${ }^{92}$ does not formally follow the EcAp, although its approach does mirror some

82 UK Parliament, 'Second Special Report of Session 2017-2019', 23 July 2018, available at: https://publications.parliament.uk/pa/cm201719/cmselect/cmhs2/1452/145202.htm.

83 High Speed Two (HS2) Ltd, 'HS2 Phase 2a: High Speed Rail (West Midlands to Crewe) Bill', 18 July 2017, updated 9 Oct. 2020, available at: https://www.gov.uk/government/collections/high-speed-railwest-midlands-to-crewe-bill.

84 C.L. Leihton \& C.R. Denis, 'Risk Assessment of a New High-Speed Railway' (1993) 5(1) IMA Journal of Management Mathematics, pp. 211-25.

85 UK House of Commons, Environmental Audit Committee, 'HS2 and the Environment', $13^{\text {th }}$ Report of Session 2013-14, 2 Apr. 2014, para. 13.

$86 R$ (on the application of HS2 Action Alliance Ltd) (Appellant) v. Secretary of State for Transport \& Anor (Respondents) (2014) UKSC 3 (on appeal from (2013) EWCA Civ 920; (2013) EWHC 481 Admin).

87 Directive 92/43/EC on the Conservation of the Natural Habitats and of Wild Fauna and Flora [1992] OJ L 206/22 (Habitats Directive).

88 Directive 2001/42/EC on the Assessment of the Effects of Certain Plans and Programmes on the Environment [2001] OJ L 197/30 (enforcing the Protocol on Strategic Environmental Assessment (SEA Protocol) to the UNECE Convention on Environmental Impact Assessment in a Transboundary Context, Espoo (Finland), 25 Feb. 1991, in force 10 Sept. 1997, available at: https://www.unece.org/ fileadmin/DAM//env/eia/eia.htm.

89 Directive 2014/52/EC amending Directive 2011/92/EC on the Assessment of the Effects of Certain Public and Private Projects on the Environment [2014] OJ L 124/1.

90 Department for Transport \& High Speed Two (HS2) Ltd, 'HS2 Judicial Review: The Challenges and Judges Ruling', 15 Mar. 2013, available at: https:/www.gov.uk/government/publications/hs2-judicialreview-the-challenges-explained.

$91 \mathrm{R}$ (on the application of HS2 Action Alliance Ltd), n. 86 above.

92 High Speed Two (HS2) Ltd is a public body wholly owned by the Department for Transport. This company is responsible for developing and promoting the UK's HS2 rail network and is funded by grant-in-aid from the UK government. 
of the EcAp principles. For example, the HS2 Phase One Environmental Statement ${ }^{93}$ and the Supplementary Environmental Statement (Phase $2 \mathrm{a})^{94}$ provide some protection for AW. These documents, firstly, highlight the importance of the involvement of landowners as stakeholders, especially those who possess specific knowledge. Secondly, they look further into potential negative environmental impacts - including socioeconomic, farming, and ecological effects - thus comprehensively reviewing the land in context. However, this is where the positive influence of the EcAp seems to diminish: these documents only set baselines for environmental concerns and do not influence any specific action that needs to be taken. ${ }^{95}$

The EcAp also advocates decentralization, which is reflected in the HS2 localized plans. Firstly, the Camden Specific Tree Panel brought together the local authority and the local community to assess the necessity for tree removal and compensation. ${ }^{96}$ Secondly, tree planting programmes and compensation plans were created by High Speed Two (HS2) Ltd which would 'replace, preserve and enhance wildlife habitats', ${ }^{97}$ and the company has allocated funds towards HS2 compensatory tree planting. ${ }^{98}$ A separate HS2 Woodland Fund, managed by the Forestry Commission, has been established to help local landowners to restore PAWS sites and create new native woodland. ${ }^{99}$ These localized plans followed the environmental minimum requirements under the HS2 environmental statement ${ }^{100}$ and are aimed to comply with relevant laws such as the Habitats Directive ${ }^{101}$ and Carbon Management Plans. ${ }^{102}$ The HS2

93 Department for Transport and High Speed Two (HS2) Ltd, 'HS2 Phase One Environmental Statement' (to accompany the High-Speed Rail (London-West Midlands) Bill), Nov. 2013, paras 2.5.14, 8.1.19, available at: https://www.gov.uk/government/collections/hs2-phase-one-environmental-statement-documents.

94 High Speed Two (HS2) Ltd, 'High Speed Rail (West Midlands to Crewe), Supplementary Environmental Statement 1 and Additional Provision 1 Environmental Statement: Vol. 3 - Route-Wide Effects', Mar. 2018; High Speed Two (HS2) Ltd, 'High Speed Rail (West Midlands to Crewe): Vol. 3 - Route-Wide Effects for the HS2 Phase 2a Supplementary Environmental Statement 2 and Additional Provision 2 Environmental Statement', available at: https://www.gov.uk/government/collections/hs2-phase-2a-environmental-statement.

95 Ibid.

96 Lord Callanan, 'High Speed Railway Line: Camden', 27 July 2017, UIN HL1135, available at: https://www.parliament.uk/business/publications/written-questions-answers-statements/written-question/ Lords/2017-07-20/HL1135.

97 High Speed Two (HS2) Ltd, 'New $£ 5$ Million Fund to Create and Restore Woodlands', Parliament Press Release, 9 Nov. 2017, available at: https://www.gov.uk/government/news/new-5-million-fund-to-createand-restore-woodlands.

98 High Speed Two (HS2) Ltd has allocated funds for tree planting over HS2 Phase One (London to the West Midlands) to 2024: Forestry Commission, 'Government Supported New Planting of Trees in England: Report for 2018-19', available at: https://assets.publishing.service.gov.uk/government/uploads/system/ uploads/attachment_data/file/808858/Government-supported-new-planting-trees-England-2018-19-.pdf.

99 Forestry Commission, 'Guidance: HS2 Woodland Fund', 4 Feb. 2020, available at: https://www.gov.uk/ guidance/hs2-woodland-fund.

100 Department for Transport, 'High Speed Rail (London-West Midlands) Environmental Minimum Requirements: General Principles', Feb. 2017, available at: https://assets.publishing.service.gov.uk/government/uploads/system/uploads/attachment_data/file/618074/General_principles.pdf.

101 N. 87 above.

102 Department for Transport, 'High Speed Rail (London-West Midlands) Environmental Minimum Requirements, Annex 4: Environmental Memorandum', Feb. 2017, available at: https://assets.publish ing.service.gov.uk/government/uploads/system/uploads/attachment_data/file/593596/Environmental_ Memorandum.pdf. 
project also focused on creating 'zero net loss in biodiversity'. With this, the project proponents envisaged that ecosystems that were damaged and destroyed by the project would be recreated and compensated for. Although the HS2 project aims to mitigate AW loss ${ }^{103}$ or, as a last resort, use compensation methods such as translocation or new woodland creation, ${ }^{104}$ they focus only on the tangible benefits of the woodland. The project's aim to have 'no net loss of biodiversity' does not look at AW specifically; it ignores the loss of particular ecosystems and skews the statistics, which makes the compensation plans look more effective on paper than they are in reality.

The prioritization of economic value is evidenced in the recent Oakervee Review. In August 2019, the government halted the HS2 project and ordered an independent review. ${ }^{105}$ The so-called Oakervee Review, published in February 2020, acknowledged that 'planting new woodland is not a direct replacement for removing areas of ancient woodland'. ${ }^{106}$ Mirroring adaptive management, it adds that 'impacts, along with any accompanying mitigation and compensatory measures, need to be kept under review $^{107}$ and that:

[t] he full extent of HS2's environmental and social impact is not captured in the benefitcost ratio. Adverse impacts during construction in the form of increased carbon, noise and air quality as well as the permanent removal of ancient woodland and land and property are not captured either. ${ }^{108}$

Although the Review puts forward several recommendations, it concludes that 'on balance, Ministers should proceed with the HS2 project'. ${ }^{109}$ Arguably, the Review fails to provide stronger protection for AW as it does not consider the national importance and the multiple values of such irreplaceable woodland. Instead, it considers the loss of AW only in the context of the economic benefits and costs of the HS2 project. Government publications on the HS2 project include reassuring statements which suggest that its efforts reflect an environmentally concerned viewpoint. ${ }^{110}$ However, the Woodland Trust views this HS2 project as a huge step back for AW protection and opposes the

103 Department for Transport, 'Phase One: London-West Midlands Ancient Woodland Strategy', Aug. 2017, available at: https://assets.publishing.service.gov.uk/government/uploads/system/uploads/attachment_data/file/664737/hs2_phase_one_ancient_woodland_strategy.pdf.

104 Ibid.

105 Department of Transport, 'Government Announces Independent Review into HS2 Programme', 21 Aug. 2019, available at: https://www.gov.uk/government/news/government-announces-independent-reviewinto-hs2-programme.

106 Department of Transport and High Speed Two (HS2) Ltd, 'Oakervee Review of HS2', 11 Feb. 2020, available at: https://assets.publishing.service.gov.uk/government/uploads/system/uploads/attachment_ data/file/864842/oakervee-review.pdf.

107 Ibid., Conclusion 8, p. 47.

108 Ibid., Review, p. 101, para. 11.13.

109 Ibid., Executive Summary, p. 11.

110 UK House of Commons, Environmental Audit Committee, 'HS2 and the Environment: Government Response to the Committee's Thirteenth Report of Session 2013-14', Second Special Report of Session 2014-15, 11 June 2014. 
project on the ground that it will destroy an alarming volume of irreplaceable ecosystems that cannot be compensated for. ${ }^{111}$

The HS2 project shows that trade-offs arise between pursuing national economic development, on the one hand, and the need to reconcile social and environmental concerns, on the other. Even though compromises have been struck between stakeholders during the negotiation phase of the project, the HS2 project has given rise to diverging views which cannot be reconciled. In reality, the optimistic goals of the EcAp are hard to implement if the values are based on subjective importance that stakeholders attribute to AW. Furthermore, it is difficult to consider context and long-term approaches in a landscape that is undergoing enormous as well as irreversible changes.

\section{PROTECTING ANCIENT WOODLAND THROUGH LAWS AND POLICIES IN THE UK}

There is little explicit statutory protection for AW in the UK. Tree-felling laws require licences for the removal of healthy trees to limit unnecessary loss, ${ }^{112}$ and several laws broadly protect forest conservation. ${ }^{113}$ However, gaps in forestry law make it difficult to provide specific protection for AW. ${ }^{114}$ It is important to note that, over the years, forestry laws and policies have been influenced partly by international ${ }^{115}$ and EU law and policy such as Natura 2000, ${ }^{116}$ which comprises a series of protected sites for the breeding and resting of threatened species. However, these international and EU enactments provide no specific guidance on protection of AW.

\subsection{Natura 2000 and Other International Frameworks}

Natura 2000 is considered the 'cornerstone of biodiversity protection in the EU by helping [to] maintain and restore important habitats and species'. ${ }^{117}$ Natura 2000 is a network of protected areas that are designated under the Habitats Directive ${ }^{118}$ and the

111 Woodland Trust, 'HS2 Green Corridor Nothing More than Greenwash Nonsense', June 2018, available at: https://www.woodlandtrust.org.uk/press-centre/2018/06/hs2-green-corridor; R. Barnes, 'Proof of Evidence on Nature Conservation \& Ecology Pertaining to Ancient Woodland and Ancient Trees Affected by HS2 Phase 1', undated, available at: http://www.hs2amersham.org.uk/Resources/Petitions/ Orgs/Slides/A2104_Barnes.pdf.

112 DEFRA, 'Felling Licences', available at: https://www.daera-ni.gov.uk/articles/felling-licences.

113 Forestry Commission England et al., n. 38 above; e.g., Town and Country Planning (Environmental Impact Assessment) Regulations 2017, Sch. 3; Wildlife and Countryside Act 1981; Countryside and Rights of Way Act 2000; Natural Environment and Rural Communities Act 2006; Environmental Impact Assessment (Forestry) Regulations 1990 (as amended in 2006).

114 O. Tickell, Why the UK's Ancient Woodland Is Still under Threat (Woodland Trust, 2000), available at: http://www.wbrc.org.uk/atp/Ancient\%20Woodland\%20Threats\%20-\%20Woodland\%20Trust.pdf.

115 Forestry Commission England et al., n. 38 above.

116 European Commission, Directorate-General for Environment, 'Natura 2000', available at: https://ec.europa.eu/environment/nature/natura2000/index_en.htm.

117 Science for Environment Policy, 'The Value of Natura 2000', Future Brief 12, May 2015, available at: https://ec.europa.eu/environment/integration/research/newsalert/pdf/value_of_natura_2000_FB12_en.pdf.

${ }^{118}$ N. 87 above. The objective of the Habitats Directive is to promote biodiversity by requiring Member States to take measures to maintain or restore the favourable conservation status of natural habitats and wild species. 
Birds Directive; ${ }^{119}$ the network includes both terrestrial and marine sites. These Directives establish the legislative framework for Natura 2000 areas to ensure the longterm survival of species and habitats. The sites are selected and proposed by the Member States. The aim of Natura 2000 is to create habitats on public and private sites where other species and human activities can interact harmoniously. ${ }^{120}$ There are concerns, however, that the overall conservation value of Natura 2000 is unclear ${ }^{121}$ and there is a need to improve the quality of environmental impact assessments, address knowledge gaps, widen stakeholder engagement, and establish a specific Natura 2000 fund. ${ }^{122}$

There are around 900 Natura sites in the UK, with Special Areas of Conservation (SACs) and Sites of Special Scientific Interest (SSSIs) as examples. ${ }^{123}$ These sites provide high levels of protection for species and habitats. ${ }^{124}$ Strategic priorities for investment in Natura 2000 sites include maintaining and restoring woodland sites, with targeted woodland creation in adjacent areas. ${ }^{125}$ While the management of and investments in Natura 2000 contribute to the UK woodland policy objectives, the overall conservation status of Natura 2000 habitats and species in the UK remains 'largely unfavourable'. ${ }^{126}$ Reports on the management of Natura 2000 sites in England underscore a budgetary constraint as well as insecurity regarding long-term funding, ${ }^{127}$ and note the political change following the UK's exit from the EU. ${ }^{128}$ It should be noted that the UK Habitats and Species Regulations ${ }^{129}$ will continue to operate as they have been rolled over into domestic legislation. Moreover, the UK will continue to meet the obligations set out in the Convention on the Conservation of European Wildlife

119 Directive 2009/147/EC on the Conservation of Wild Birds [2010] OJ L 20/7. The objective of the Birds Directive is to implement special measures to maintain the favourable conservation status of wild birds throughout Europe.

120 'Natura 2000', n. 116 above.

121 M. Davis et al., 'Literature Review: The Ecological Effectiveness of the Natura 2000 Network', 1 Nov. 2014, ETC/BD Technical Paper No. 5/2014, available at: https:/www.eionet.europa.eu/etcs/etc-bd/products/etc-bd-reports/the_ecological_effectiveness_of_the_natura_2000_network; K. Bastmeijer, 'The Ecosystem Approach for the Marine Environment and the Position of Humans: Lessons from the EU Natura 2000 Regime', in D. Langlet \& R. Rayfuse (eds), The Ecosystem Approach in Ocean Planning and Governance: Perspectives from Europe and Beyond (Brill, 2018), pp. 195-220.

122 Ibid.; see also V. Kati et al., 'The Challenge of Implementing the European Network of Protected Areas Natura 2000' (2015) 29(1) Conservation Biology, pp. 260-70.

123 Natural England, 'Natura 2000: European Wildlife Sites', available at: https://consult.defra.gov.uk/naturalengland/crouch-roach-estuaries/supporting_documents/European \%20leaflet\%20Natura\%202000.pdf.

124 J.H. Lawton et al., 'Making Space for Nature: A Review of England's Wildlife Sites and Ecological Network, Report to Defra' (2010), pp. 1-107, available at: https://www.researchgate.net/publication/ 268279426_Making_Space_for_Nature_A_Review_of_England\%27s_Wildlife_Sites_and_Ecological_ Network.

125 Joint Nature Conservation Committee (JNCC), 'Format for a Prioritised Action Framework (PAF) for Natura 2000: England', 2016.

126 Ibid., p. 10.

127 Natural England, 'Improvement Programme for England's Natura 2000 Sites (IPENS): Planning for the Future: Summary Report, 2015, available at: https://assets.publishing.service.gov.uk/government/ uploads/system/uploads/attachment_data/file/481444/ipens-summary-report.pdf.

128 Natural England, 'Improvement Programme for England's Natura 2000 Sites (IPENS), Implementation Progress Report 2015-2018', 11 June 2018, available at: http://publications.naturalengland.org.uk/publication $/ 6630490718601216$ ? category $=4878851540779008$.

129 Conservation of Habitats and Species (Amendment) (EU Exit) Regulations 2019, UK Statutory Instrument 2019 No. 579. 
and Natural Habitats, ${ }^{130}$ which is of particular relevance to Natura 2000. EU Member States currently meet their obligations under the Convention by means of the Habitats and Birds Directives and the UK will continue to meet such obligations through the Habitats and Species Regulations.

While international law lacks binding instruments explicitly to protect AW, several international soft laws related to forest conservation offer guidance. ${ }^{131}$ For instance, the UK is committed to follow the 1992 UN Forest Principles, ${ }^{132}$ which focus on protecting biodiversity, long-term conservation and the avoidance of any damage to ecosystems. International policies adopted under the auspices of binding treaties such as the CBD, ${ }^{133}$ including the Sustainable Forestry in the UK Programme, have also introduced EcAp responsibilities to the UK. Based on the UK's commitments under the CBD, the UK Department for Environment, Food and Rural Affairs (DEFRA) has formulated an EcAp action plan and developed the 2017 Forestry Standards. ${ }^{134}$ However, fragmented policies in relation to the EcAp and the absence of laws that offer explicit protection of AW remain a challenge.

\subsection{Fragmented Ancient Woodland Protection Policies in the UK}

The EcAp typically has been integrated into UK law as an optional approach. The Joint Nature Conservation Committee of the UK (JNCC), a statutory advisory committee, follows the CBD in defining the EcAp as 'a concept that integrates the management of land, water and living resources and aims to reach a balance between three objectives: conservation of biodiversity; sustainable use; and equitable sharing of benefits arising from the utilisation of natural resources' ${ }^{135}$ Along with statements by the JNCC, various documents from the Parliamentary Office of Science and Technology, ${ }^{136}$ DEFRA, ${ }^{137}$ and Natural England ${ }^{138}$ underscore that the UK approach towards integrating the EcAp into environmental protection policy strengthens the link between intangible environmental benefits and tangible human benefits, and aims to balance stakeholders' different values which are crucial for AW protection.

Policies such as the government's Ancient and Native Woodland Policy Targets for 2020 (2005) emphasize the protection of the social, economic, and environmental

${ }^{130}$ Bern (Switzerland), 19 Sept. 1979, in force 1 June 1982, available at: http://www.coe.int/t/dg4/cultureheritage/nature/bern/default_en.asp.

${ }^{131}$ Forestry Commission England et al., n. 38 above.

${ }^{132}$ UN Conference on Environment and Development, 'Non-Legally Binding Authoritative Statement of Principles for a Global Consensus on the Management, Conservation and Sustainable Development of All Types of Forests' (1992), UN Doc. A/CONF.151/6/Rev.1.

${ }^{133}$ N. 61 above.

134 Forestry Commission England et al., n. 38 above.

135 JNCC, 'Ecosystem Approach', available at: http://jncc.defra.gov.uk/default.aspx? page=6276.

136 UK Houses of Parliament, n. 77 above.

137 DEFRA, 'Enabling a Natural Capital Approach: Guidance', Jan. 2020, available at: https:/assets.publishing.service.gov.uk/government/uploads/system/uploads/attachment_data/file/858808/natural-capital-encaguidance-pdf.pdf.

138 J. Porter et al., Ecosystem Approach Handbook (Countryscape, 2014), available at: https://ecosystemsknowledge.net/sites/default/files/wp-content/uploads/2016/1/ecosystem-approach-handbook.pdf. 
benefits that woodland provides. ${ }^{139}$ The policy aims to create new woodland to make increasing contributions to the quality of life and sustainable development for enterprise and employment as well as maintaining ecological conditions. ${ }^{140}$ The 2007 Ecosystem Approach Action Plan for the natural environment contains reference to 'a generic ecosystems approach that can be applied in a wide range of policy areas and decision-making contexts'. ${ }^{141}$ However, this Action Plan by DEFRA does not refer specifically to AW. To promote the integration of the EcAp, the UK conducted a National Ecosystem Assessment in 2011 and a follow-on report in 2014. This wideranging assessment identifies the benefits that AW creates, and enables monitoring and the adoption of maintenance guidelines for specific habitats. ${ }^{142}$ In 2013, DEFRA produced the forestry and woodlands policy statement that highlights the importance of AW and confirms the government's commitment 'to valuing the many social and environmental benefits of woodlands and to developing new market opportunities'. ${ }^{143}$

Arguably, the EcAp has not reached its full potential in the UK as the policy guidelines are not binding. In addition, the inclusion of market-based approaches may give rise to unexpected negative impacts as the policies ${ }^{144}$ cannot be detached from their environmental and social dimensions. There has been a recent shift in the UK towards a natural capital approach as 'it offers a balanced focus on natural assets in ecological terms (their quantity, condition and sustainability) and the social and economic benefits that derive from those assets'. ${ }^{145}$ Such an approach may facilitate a dialogue on the diverse values of nature and employ participatory processes. However, to enable this possibility, the natural capital approach needs to recognize the trade-offs and long-term goals of AW conservation.

139 DEFRA \& Forestry Commission England, 'Keepers of Time: A Statement of Policy for England's Ancient and Native Woodlands', 2005, available at: https:/assets.publishing.service.gov.uk/government/uploads/ system/uploads/attachment_data/file/778106/KeepersofTimeanw-policy.pdf; Forestry Commission England, 'Managing Ancient \& Native Woodland in England: Practice Guide', 2010, available at: https://assets.publishing.service.gov.uk/government/uploads/system/uploads/attachment_data/file/720995/ FCPG201.pdf.

140 DEFRA, 'A Strategy for England's Trees, Woods and Forests', 2007, available at: http://webarchive.nationalarchives.gov.uk/20090809182116/http:/www.defra.gov.uk/wildlife-countryside/pdf/forestry/20070 620-forestry.pdf.

141 DEFRA, 'Securing a Healthy Natural Environment: An Action Plan for Embedding an Ecosystems Approach', 2007, available at: https:/ecosystemsknowledge.net/sites/default/files/wp-content/uploads/ Defra\%20eco-actionplan.pdf.

142 UK National Ecosystem Assessment, 'UK National Ecosystem Assessment Technical Report', 2011, available at: http://uknea.unep-wcmc.org/LinkClick.aspx?fileticket=m\%2bvhAV3c9uk\%3d\&tabid=82; S. Albon et al., 'UK National Ecosystem Assessment Follow-on: Synthesis of Key Findings', June 2014, available at: http://uknea.unep-wcmc.org/Resources/tabid/82/Default.aspx.

143 DEFRA, n. 39 above, p. 4.

144 E.g., DEFRA, n. 39 above; HM Government, 'A Green Future: Our 25 Year Plan to Improve the Environment', 2018, available at: https://assets.publishing.service.gov.uk/government/uploads/system/ uploads/attachment_data/file/693158/25-year-environment-plan.pdf.

145 DEFRA, 'Enabling a Natural Capital Approach: Guidance', Jan. 2020, available at: https://assets.publish ing.service.gov.uk/government/uploads/system/uploads/attachment_data/file/858808/natural-capitalenca-guidance-pdf. 
Planning laws give the UK government limited control over AW. ${ }^{146}$ The 2019 National Planning Policy Framework ${ }^{147}$ states specifically that AW should be viewed as an irreplaceable habitat - stronger wording than in the previous version. The Woodland Trust welcomed this change as it offers 'ancient woodland equal status with listed buildings and national parks' ${ }^{148}$ Therefore, planning permission cannot be granted without a compensation plan and exceptional reasons. ${ }^{149}$ Exceptional reasons include 'nationally significant infrastructure projects' and situations 'where the public benefit would clearly outweigh the loss or deterioration of habitat'. ${ }^{150}$ While this provision sets a high threshold, large projects similar to the HS2 (discussed above) - a nationally significant infrastructure - are likely to go ahead. The Forestry Commission as well as the Woodland Trust's guidance for planning authorities provide more specific provision on mitigation, compensation, and adequate buffers. ${ }^{151}$ Although they do not formally integrate the EcAp, these guidelines begin to look past individual pieces of land to assess effects across ecosystems and also listen to the needs of stakeholders. At the same time there is a clear acceptance of trade-offs between economic development and nature conservation objectives.

\subsection{Laws that Offer General Protection for Ancient Woodland}

A number of general legal provisions in the UK can be interpreted to include the EcAp. For example, the Countryside and Rights of Way Act 2000 imposes a general duty on all governmental departments 'in carrying out his or its functions, to have regard, ... to the purpose of conserving biological diversity in accordance with the Convention [on Biological Diversity]'. ${ }^{152}$ The Natural Environment and Rural Communities Act 2006 extends this obligation to all public bodies, including the Forestry Commission. ${ }^{153}$ Another example is the Forestry Act 1967, which has stricter standards for the care of trees within conservation areas. ${ }^{154}$ Moreover, legislation such as the Wildlife and Countryside $\mathrm{Act}^{155}$ includes provisions on nature conservation

\footnotetext{
146 Town and Country Planning Act 1990; Planning Act 2008.

147 Ministry of Housing, Communities and Local Government, 'National Planning Policy Framework', Feb. 2019, para. 175 and Annex 2, available at: https://assets.publishing.service.gov.uk/government/uploads/ system/uploads/attachment_data/file/810197/NPPF_Feb_2019_revised.pdf.

148 Woodland Trust, 'The Voice for Woods and Trees: Reports and Accounts', 31 Dec. 2018, available at: https://www.woodlandtrust.org.uk/media/43727/report-and-accounts-2018.pdf.

149 Forestry Commission, 'Planning Applications Affecting Trees and Woodland', 2018, available at: https:/www.gov.uk/guidance/planning-applications-affecting-trees-and-woodland.

150 National Planning Policy Framework, Feb. 2019, para. 1765(c), available at: https://assets.publishing.service.gov.uk/government/uploads/system/uploads/attachment_data/file/810197/NPPF_Feb_2019_ revised.pdf.

151 Forestry Commission and Natural England, 'Ancient Woodland, Ancient Trees and Veteran Trees: Protecting Them from Development', 2018, available at: https://www.gov.uk/guidance/ancient-woodland-and-veteran-trees-protection-surveys-licences; Woodland Trust, 'Planning for Ancient Woodland: Planners' Manual for Ancient Woodland and Veteran Trees', July 2019, available at: https://www.woodlandtrust.org.uk/media/3731/planners-manual-for-ancient-woodland.pdf.

152 Countryside and Rights of Way Act 2000, s. 74.

153 Natural Environment and Rural Communities Act 2000, Sch. 7 (Designated Bodies).

154 Forestry Act 1967, as amended by the Wildlife and Countryside Act 1981.

155 Wildlife and Countryside Act 1981, as amended by the Countryside and Rights of Way Act 2000.
} 
and heritage preservation, and moves the law towards incorporating the non-economic value of woodlands. ${ }^{156}$ These laws have general application to AW but fail to provide specific protection. This could be partly because of the resource-intensive process of defining and classifying woodland. The Woodland Trust has criticized the UK approach to woodland management and the lack of clear, enforceable policies to protect it. It notes the continued loss of healthy woodland as a result of poor management, and the creation of housing, new leisure spaces, roads, and business developments from car parks to telephone masts. ${ }^{157}$ In this area, a clearly defined and practical application of the EcAp is missing from AW protection.

One option for the protection of AW is to confer protected status. ${ }^{158}$ Protected areas are often used globally to conserve forest biodiversity, although the effectiveness of such protection is questioned as a result of weak political commitment, lack of funding, and poor enforcement measures. ${ }^{159}$ There are many forms of area status in the UK, each focusing on different features of an ecosystem. For example, the Area of Outstanding Natural Beauty (AONB) designation under the National Parks and Access to the Countryside Act $1949^{160}$ protects a wide range of wildlife, scenery, and heritage. A series of Sites of Specific Scientific Interest (SSSIs) have developed since the National Parks and Access to the Countryside Act, and the Wildlife and Countryside Act ${ }^{161}$ provides more specific protection and management requirements. ${ }^{162}$ Special Areas of Conservation (SACs) are derived from the Habitats Directive ${ }^{163}$ and protect species detailed in Annex 1 and 11 of the Directive, which are viewed as representative of EU habitats. AW is included in all of these types of protected area through either tree type (such as in the Cotswolds AONB in England ${ }^{164}$ ), mixed broad leaves under the UK Biodiversity Action Plan, ${ }^{165}$ or Ancient Oaks which fall under Annex 1 of the Habitats Directive. ${ }^{166}$ These protected areas cover much land and can regulate important ecosystem values. However, according to the Woodland Trust, AW in the

156 Raum, n. 11 above.

157 D. Smith, 'Number of Threatened Ancient Woodlands Tops the Thousand Mark', Woodland Trust, 14 Jan. 2020, available at: https://www.woodlandtrust.org.uk/press-centre/2020/01/thousand-threatened-ancient-woods.

158 UK Houses of Parliament, n. 15 above.

159 D. Morales-Hidalgo, S.N. Oswalt \& E. Somanathan, 'Status and Trends in Global Primary Forest, Protected Areas, and Areas Designated for Conservation of Biodiversity from the Global Forest Resources Assessment 2015' (2015) 352 Forest Ecology and Management, pp. 68-77.

160 National Parks and Countryside Act 1949, as amended by the Environment Act 1995.

161 Wildlife and Countryside Act 1981, n. 155 above.

162 JNCC, 'Guidelines for Selection of SSSIs', available at: https://jncc.gov.uk/our-work/guidelines-for-selection-of-sssis.

163 N. 87 above.

164 Cotswolds Conservation Board, 'Woodland', 2018, available at: https://www.cotswoldsaonb.org.uk/ our-landscape/woodland.

165 Priority habitats are protected by the UK Biodiversity Action Plan, which helps to protect semi-natural habitats and threatened habitats recognized in the Action Plan: JNCC, 'The UK Biodiversity Action Plan 1994', available at: https:/hub.jncc.gov.uk/assets/cb0ef1c9-2325-4d17-9f87-a5c84fe400bd.

166 JNCC, 'Coetiroedd Cwm Elan/Elan Valley Woodlands', undated, available at: http://jncc.defra.gov.uk/ ProtectedSites/SACselection/sac.asp?EUCode=UK0030145. 
UK 'is poorly represented' with only a limited amount of it protected under SSSI status. $^{167}$

\section{CERTIFICATION SCHEMES AND THE PROTECTION OF ANCIENT WOODLAND}

A frequently used strategy to apply the EcAp to the protection of woodland is through certification. Certification schemes are driven partly by the perceived inadequacy of legal protection and they promise integration of multiple values and cooperation among stakeholders. Forest certification, an economic instrument introduced in the early 1990s to improve forest management, can help to address concerns of deforestation and forest degradation. Such certification can promote the conservation of biological diversity and deforestation-free supply chains. ${ }^{168}$ For instance, certification has been found to have positive impacts in terms of forest regeneration and biodiversity conservation, as well as positive social impacts, such as improved levels of discussion among forestry companies and local communities, and benefit sharing. ${ }^{169}$ Yet there is also criticism of different international certification schemes and forest certification more generally, as most certified forests are situated in developed countries, whereas many developing countries lack enabling conditions to implement certification schemes. ${ }^{170}$

Certification is a means for public and private bodies to monitor forest management behaviour at international and national levels, and the certification systems that operate on a global scale have greatly affected how forests are managed in the UK. In the context of woodland protection the integration of the EcAp in forest certification can help to balance multiple values of woodland and move away from purely economic values ${ }^{171}$ by removing market distortion and creating incentives to promote social benefits. ${ }^{172}$ The downside is that, when proceduralized into a certification scheme, the EcAp could lose its ability to adapt to the needs of ecosystems and provide a proactive system.

Two main international schemes influence the development of forest certification in the UK. One is Forest Stewardship Council (FSC) certification, ${ }^{173}$ which is global. The

167 Select Committee on Environment, Food and Rural Affairs, 'Memorandum Submitted by the Woodland Trust (N1), Session 2003-04', available at: https://publications.parliament.uk/pa/cm200304/cmselect/ cmenvfru/475/475we02.htm.

168 O. Damette \& P. Delacote, 'Unsustainable Timber Harvesting, Deforestation and the Role of Certification' (2011) 70(6) Ecological Economics, pp. 1211-9; CBD Secretariat, n. 12 above.

169 J. Razzaque \& I. Visseren-Hamakers, 'Options for Decision-Makers', in IPBES, Global Assessment Report of the Intergovernmental Science-Policy Platform on Biodiversity and Ecosystem Services (IPBES, 2019), pp. 1-260, at 55-6.

170 CBD Secretariat, n. 12 above, paras 14-5; E. Rametsteiner \& M. Simula, 'Forest Certification: An Instrument to Promote Sustainable Forest Management?' (2003) 67(1) Journal of Environmental Management, pp. 87-98.

${ }^{171}$ Raum, n. 11 above.

${ }^{172}$ H. Garrelts \& M. Flitner, 'Governance Issues in the Ecosystem Approach: What Lessons from the Forest Stewardship Council?’ (2011) 130(3) European Journal of Forest Research, pp. 395-405.

${ }^{173}$ Forest Stewardship Council (FSC), 'FSC Certification', available at: https://ic.fsc.org/en/what-is-fsccertification. 
FSC has had positive impacts on biodiversity conservation and ecological outcomes such as forest structure, regeneration, and lower fire incidents. ${ }^{174}$ The other is the Programme for the Endorsement of Forest Certification (PEFC) ${ }^{175}$ scheme, which aims to be adaptable to the needs of each country and is applied in the UK. ${ }^{176}$ The UK has created its own certification standard - the UK Woodland Assurance Standard (UKWAS) ${ }^{177}$ - to reflect the requirements of the FSC and PEFC schemes. This national certification standard is tailored to the needs of managing UK woodland and could offer better protection for AW and guidance to managers. The fourth edition of the UKWAS was introduced in 2018 and was subsequently adopted for use in the UK by both the FSC and the PEFC. The major woodland owners in the UK - such as the Forestry Commission, the Woodland Trust, the National Trust and the Royal Society for the Protection of Birds - follow the UKWAS and have FSC certification. ${ }^{178}$

The UKWAS supports the conservation of ASNW sites and PAWS and encourages the restoration of AW in its guidelines on biodiversity. It identifies options for managing PAWS, which range from the maintenance of biodiversity within an otherwise conventionally managed plantation to full restoration. The UKWAS asks forest owners and managers to adopt a precautionary approach to maintain and enhance (where possible) the high conservation value of ASNW sites. ${ }^{179}$ It adds that the 'owner/manager shall maintain and enhance or restore features and areas of high conservation value within plantations on ancient woodland sites'. 180

The FSC certification standard for the UK has taken steps towards better practices to protect AW. It has banned chemicals, including fertilizer used specifically to increase timber production. ${ }^{181}$ This is a positive step. It also states that 'areas converted from ancient and other semi-natural woodlands ... shall not normally qualify for certification' 182 and 'all ancient semi-natural woodlands and plantations on ancient woodland sites are considered to be of high conservation value'. ${ }^{183}$ However, it can be argued that the use of the word 'normally' implies that certification of such woodland 'may be

174 S.K. Kalonga, F. Midtgaard \& K. Klanderud, 'Forest Certification as a Policy Option in Conserving Biodiversity: An Empirical Study of Forest Management in Tanzania' (2016) 362 Forest Ecology and Management, pp. 1-16.

175 Programme for Endorsement of Forest Certification Council (PEFC), 'Mission and Vision: PEFC Strategy 2018-2022', 2018, available at: https://cdn.pefc.org/pefc.org/media/2019-03/d0a32b21-f6eb-49f8bb50-70405a13babd/cc628185-a9c7-53e1-b513-30a4b15d55c8.pdf.

176 PEFC, 'Sustainable Forest Management', June 2018, available at: https://www.pefc.org/standards/sustainable-forest-management.

177 UK Woodland Assurance Standard, $4^{\text {th }}$ edn, version 4.0, 1 Apr. 2018, available at: http://ukwas.org.uk/ wp-content/uploads/2018/05/UKWAS_Standard_FourthEdition_digital.pdf.

178 FSC UK, available at: https://www.fsc-uk.org/en-uk.

179 UK Woodland Assurance Standard, n. 177 above, Ch. 4 (Natural, Historical and Cultural Environment), Standard 4.2 (Conservation of Ancient Semi-Natural Woodlands) and 4.3 (Management of Plantations on Ancient Woodland Sites).

180 Ibid., Standard 4.3.1.

181 FSC, 'The FSC National Forest Stewardship Standard of the United Kingdom', 1 Apr. 2018, Criteria 10.6 and 10.7, available at: https://www.fsc-uk.org/preview.fsc-forest-management-standard-for-the-uk-fscstd-gbr-03-2017.a-971.pdf.

182 Ibid., Indicator 6.10.1.

183 Ibid., Indicator 9. 
allowed' in some circumstances if sufficient evidence is submitted to the certification body. ${ }^{184}$ Such discretionary language offers weak protection for AW.

Woodland owners and managers apply for certification schemes voluntarily. ${ }^{185}$ This means that they need to be enticed by benefits such as good reputation, consumer awareness, environmental considerations and social sanctions, as well as economic factors. Certifications are increasing in influence as customers are looking to certification for transparency and standards of practice. ${ }^{186}$ Recent examples of certification show a move away from purely economic concerns as certification schemes are incorporating environmental concerns and multifunctional views of the EcAp. ${ }^{187}$ Nonetheless, forest certification schemes around the world encounter several limitations. Firstly, it is impossible to make a certification that is adaptive to evolving standards and scientific knowledge and, at the same time, sufficiently uncomplicated for forest managers to follow. ${ }^{188}$ Secondly, the involvement of many stakeholders gives rise to conflicting viewpoints: one side may demand stricter schemes and the other more lenient ones, ${ }^{189}$ which makes finding acceptable standards difficult. All certification schemes can be charged with a lack of inclusive decision-making processes in that their standards are not created by an elected body. ${ }^{190}$

What role can such certification standards play to protect AW? While there is limited evidence of the impacts of the various forest certification schemes, ${ }^{191}$ the UKWAS, FSC and PEFC acknowledge the high conservation value of AW and support a precautionary approach. However, the current performance of certification standards in the UK to protect AW shows that such standards play a limited role and are marred by discretionary language. In order for such standards to be effective, a higher threshold to protect AW is needed with stronger provision on AW protection, stakeholder engagement and monitoring.

\section{DISCUSSION}

Our discussion shows that the protection of AW in the UK is influenced by a collection of international, European, and national laws. The EcAp - adapted from international law to UK forest laws - remains an ambiguous and contested concept. The legal and economic instruments applied to manage woodland in the UK evidence deep-rooted

${ }^{184}$ Ibid., Guidance Note on Indicator 6.10.1, p. 65.

185 Quine, Bailey \& Watts, n. 78 above.

186 E. Meidinger, 'Forest Certification and Democracy' (2011) 130(3) European Journal of Forest Research, pp. 407-19.

${ }^{187}$ Raum \& Potter, n. 1 above.

188 S. Eden, 'The Work of Environmental Governance Networks: Traceability, Credibility and Certification by the Forest Stewardship Council' (2009) 40(3) GeoForum, pp. 383-94.

189 B. Cashore, G. Auld \& D. Newsom, 'Forest Certification (Eco-Labeling) Programs and their Policy-making Authority: Explaining Divergence among North American and European Case Studies' (2003) 5(3) Forest Policy and Economics, pp. 225-47.

190 Meidinger, n. 186 above.

${ }^{191}$ H. van der Ven \& B. Cashore, 'Forest Certification: The Challenge of Measuring Impacts' (2018) 32 Current Opinion in Environmental Sustainability, pp. 104-11. 
anthropocentricity whereby nature is regarded as 'capital' or 'service provider'. Despite policy commitments, it is disheartening to see that challenges that are contributing to the decline of AW in the UK are similar in other parts of the world struggling to preserve AW. ${ }^{192}$ Noting that the UK government's recent environmental plan recognizes the 'significant heritage value and irreplaceable character' of AW, ${ }^{193}$ it is imperative that the UK now initiates strong laws that distinctly protect AW and integrate the EcAp approach.

The nature of AW within the UK means that it is difficult to define and document AW. Once categorized, apart from a few policies and guidelines, there is little explicit protection offered to AW. Instead, planning permissions and protected sites are taken as useful legal measures for its protection. Although not perfect, these measures contain the essence of the EcAp by incorporating different views of diverse stakeholders and acknowledging AW as part of a wider ecosystem. There is no doubt, however, that the UK government's fragmented approach needs to be backed by stronger legal instruments and specific laws that would offer better protection for AW ecosystems. The UK commitment to environmental protection and preserving the AW ecosystem is clearly stated in many policy documents. Additionally, EU law and policy, such as Natura 2000, and international forest certification schemes have offered innovative ways to manage UK woodland. However, UK laws and policy commitments need to be supported by a long-term plan that revamps the way in which we finance and prioritize conservation of AW, recognizes the importance of multiple values in AW protection, encourages concerted efforts from a range of stakeholders, and promotes the public goods aspect of AW above private profit to preserve the unique and irreplaceable ecosystem of AW.

In theory, the EcAp entails a decentralized process that integrates societal choices, rights and interests of local communities, and intrinsic as well as tangible and intangible values attached to AW. Any kind of woodland management involves various forms of interaction among those involved and, in the case of AW, the relationships between stakeholders become more complicated because of a lack of context-sensitive combinations of participatory approaches to resolve trade-offs and conflicts among objectives. The HS2 offers an example of such power struggles, stakeholder conflict, and tradeoffs. It shows that woodland-related decisions may not accommodate the interests of all stakeholders. The management of AW is far from perfect, especially when we consider its irreplaceable value, as the damage caused cannot be undone. More effective collaboration among several government bodies, as well as among woodland owners and managers in the UK engaged in promoting EcAp in AW management, over time is therefore also imperative.

Strengthening multiple strategies through policy framing - such as stakeholder connectivity, forest stewardship, accountability of public and private sectors, local capacity building, and dedicated funds - can promote the negotiation and cooperation elements of the EcAp. One positive example is the Welsh Assembly's Woodlands for Wales

192 Barton \& Keeton, n. 52 above; Burrascano et al., n. 52 above.
193 HM Government, n. 144 above, p. 47. 
strategy. Although this strategy does not explicitly follow the EcAp, it highlights the importance of woodland for people as one of its four goals. ${ }^{194}$ It links historical and cultural importance with the environmental features of the woodland, provides a woodland-specific law - unlike the piecemeal laws that govern the issue in the rest of the UK - and considers all types of owner from corporate to small private entities. It also emphasizes the importance of forest management, with specific protection for broadleaved woodland in harmony with conifers. ${ }^{195}$ This Welsh approach can further improve existing AW protection in the UK by taking the EcAp beyond linking people and forests; it could regulate and support interaction among public and private actors, provide education, and promote awareness of AW protection. Some of these measures could be adopted throughout the UK specifically to conserve its AW, along with a clear definition of the EcAp in the context of AW protection.

Conflicts between economic and non-economic values and between different groups of stakeholder prioritizing diverse values and interests are particularly relevant to forest-related decision making. The level of inclusiveness in the decision-making processes determines the negotiating power of stakeholders, reveals potentially competing values, and identifies options for more equitable decisions. In addition, the framing of the valuation process significantly influences which values are taken into account, which are omitted, and which may not be compatible with the type of measurement applied. ${ }^{196}$ The international certification schemes (such as the FSC and the PEFC) integrate a market-based approach and have offered some elements of an EcAp that unites stakeholders and recognizes the non-economic values of woodlands. However, they fail to define clearly the remit of relational and intrinsic values and are completely voluntary, which limits their reach. Within the context of AW protection, it is not only raising awareness and being inclusive that matters; the policies, assessments, and standards themselves must not undermine the value dimensions in decision making.

\section{CONCLUDING REMARKS}

The existing level of protection of AW in the UK - which is leading to the exploitation of woodland, destruction through large infrastructure projects, and inequality among stakeholders - cannot be sustainable. The problem lies in recognizing the scope of the EcAp, acknowledging the non-economic values as well as implementing more integrative and inclusive AW protection through managing trade-offs and incentivizing stakeholder engagement. Concerted efforts from both public and private actors are required to create space for information sharing, provide adequate financial incentives, monitor AW management, and revamp the way in which we prioritize conservation of AW.

\footnotetext{
${ }^{194}$ Welsh Government, 'Woodlands for Wales: The Welsh Government's Strategy for Woodlands and Trees', 2018, available at: https:/gov.wales/sites/default/files/publications/2018-06/woodlands-for-wales-strategy_0.pdf.

195 Ibid.

196 IPBES, n. 53 above.
} 